Article

\title{
Strategic Framework for Sustainable Management of Drainage Systems in Semi-Arid Cities: An Iraqi Case Study
}

\author{
Mohammed Nanekely ${ }^{1}$, Miklas Scholz ${ }^{1,2, *}$ and Furat Al-Faraj ${ }^{1}$ \\ 1 Civil Engineering Research Group, School of Computing, Science and Engineering, \\ The University of Salford, Newton Building, Salford M5 4WT, UK; \\ m.a.a.nanekely@edu.salford.ac.uk (M.N.); f.a.m.al-faraj@edu.salford.ac.uk (F.A.-F.) \\ 2 Division of Water Resources Engineering, Faculty of Engineering, Lund University, P.O. Box 118, \\ Lund 221 00, Sweden \\ * Correspondence: miklas.scholz@tvrl.lth.se or m.scholz@salford.ac.uk; Tel.: +46-222-8920; Fax: +46-222-4435
}

Academic Editor: Athanasios Loukas

Received: 20 June 2016; Accepted: 12 September 2016; Published: 19 September 2016

\begin{abstract}
For the purpose of this paper, Erbil city, located in the northern part of Iraq, has been chosen as a representative case study for a large number of cities, particularly in semi-arid areas, lacking sustainable drainage systems (SuDS). The study assesses (a) the role of SuDS as a measure in areas with a water shortage; (b) water scarcity in decision-making processes; (c) the lack of legislation to implement SuDS; (d) the adverse effects of climate change on the urban drainage system; and (e) the effects of an increased population on SuDS implementation. An integrated methodology that incorporates a self-administrated questionnaire, workshops, face-to-face communication and interviews, as well as electronic media interactions, were used to achieve the objectives. A generic platform that consists of thirteen pillars, supporting the short to long-term national policies and strategies towards a sustainable urban drainage system, has been developed. Results showed that environmental laws need to be introduced. Findings also indicate that a growing population, which is partly due to an increase of internally displaced people, is a major challenge to an early application of SuDS, due to a rise in land demand and a lack of financial resources.
\end{abstract}

Keywords: climate change; flooding; legislation; population growth; sanitation; socio-economic; sustainable framework; sustainable drainage system; urban inundation; urban ecology

\section{Introduction}

\subsection{Background}

Decades of wars combined with economic sanctions, armed conflicts, and the current insecure atmosphere has left deep scars on Iraq's environment, socio-economic features and infrastructure. A large proportion of the water supply and sanitation services are malfunctioning, which greatly intensified water-related challenges and exacerbated the size of the problems [1,2]. This has threatened human life, the environment, and the safe access to water supply and basic sanitation practices. Most people have limited or inadequate access to safe drinking water and basic sanitation facilities. Poorly trained personnel, an intermittent power supply, a sharp decrease in spare parts availability and chemicals needed to maintain the safe running of water treatment plants, inefficient operation and maintenance programmes, and a prolonged tendency that relies on curative rather than long-term sustainable solutions have intensified the problems of the water-related service delivery systems, particularly the sustainable governance of drainage systems [2-4]. 
Management of the water supply and sanitation installations in a sustainable manner in Iraq has become a crucial issue. Due to decades of armed conflicts and violence associated with loss of skills and institutional weakness, Iraq became one of the vulnerable and water insecure countries that have fragile water and sanitation services [5]. Appropriately designed and operated urban drainage systems associated with the proper operation of other urban water facilities such as domestic water supply, are fundamental parts of healthy and safe urban environments [6].

The main drivers adding to the elevated vulnerability include but are not limited to: (a) growing water demands at local, country-wide and transboundary levels; (b) a considerable decrease in yearly flow volume entering the case study country Iraq from upstream riparian countries (in particular, Turkey and Iran); (c) an impairment of water quality due to effluents of untreated contaminated wastewater and considerable return flows from large-scale irrigation projects that discharge directly into watercourses; (d) non-rational water consumption use in different sectors (particularly in agriculture); (e) inadequate water supply and sanitation practices; (f) fragmented responsibilities between different actors; $(\mathrm{g})$ weakness of dynamic and functional coordination among relevant stakeholders; (h) a lack or even absence of transparency in the exchange of information including data; (i) a significant and drastic decline in groundwater level; and (j) the absence of water withdrawal monitoring networks [4-6].

Al-Faraj et al. [5] indicated that the level of vulnerability has been exacerbated by the negative implications of decades of conflict and the associated unstable economic situation and political crisis, which weakened and delayed stakeholders' responses. Moreover, some key hydraulic structures (i.e., barrages and regulators) on the Euphrates, Tigris and Diyala rivers have been controlled by "Daesh" (also known as Islamic State) several times, which impaired the daily operational policies and water resources management strategies [7,8].

\subsection{Addressing the Challenges}

Sustainable drainage systems have been increasingly considered as promising techniques to alleviate three major water-related challenges. The problems are: (a) flash flooding; (b) imbalance between water demand and supply; and (c) water pollution $[9,10]$.

Like many other countries, Iraq has experienced the consequences of a changing climate [11-14]. Since 2010, the Iraqi people have witnessed both severe droughts and extreme rainfall events combined with flash floods that have adversely impacted on the existing water supply and sanitation systems. According to the Fifth Assessment Report of the Inter-governmental Panel on Climate Change [15], more frequent and more extreme weather events are anticipated in the years to come.

In this paper, Erbil city (capital of Kurdistan region) in the northern part of Iraq has been chosen as a representative case study for a large number of cities in semi-arid areas, which have an inadequate water supply distribution network and ineffective conventional combined urban drainage facilities. In 2014, Iraq's Kurdistan Regional Government requested that the local communities reduce their water use due to the largest shortages of water since 2000. The municipality of Erbil has imposed mandatory water rationing and indicated that it will fine those individuals violating this restriction. The washing of vehicles with drinking water has also been restricted. The increasing demand due to the rapid growth of population, increased number of internally displaced people, and the systematic squandering of fresh water, combined with frequent power outages, are the key drivers of the current water shortages [16,17].

In conjunction with the recent shortage of water, abrupt torrential rains of $28 \mathrm{~mm}, 59 \mathrm{~mm}$ and $42 \mathrm{~mm}$ in Erbil on 9 November 2015, 30 December 2015 and 29 March 2016, respectively, have resulted in flash floods [18]. Many sewers overflowed, which led sewage to escape and mix with storm water. Flooding also contributed to more power outages as many local, small power generators were flooded. Roads were damaged and drainage systems got blocked even days after it had stopped raining (Figure 1). Figure 2 shows some photos that demonstrate the failure of the drainage system in Erbil city between 1936 and 1970. 


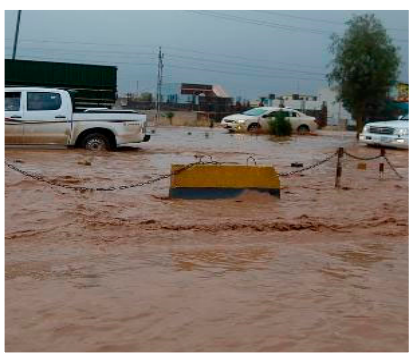

(a)

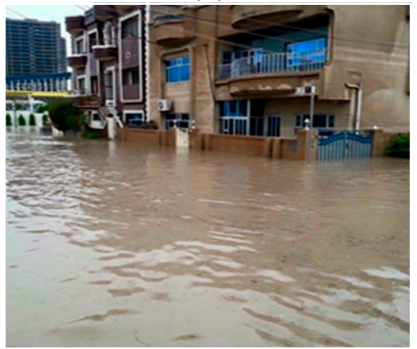

(d)

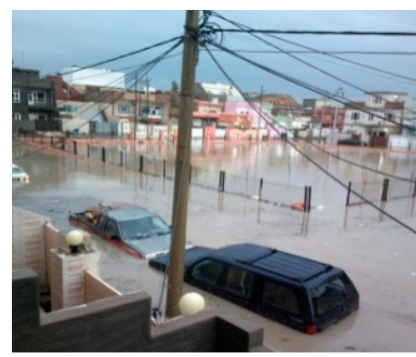

(b)

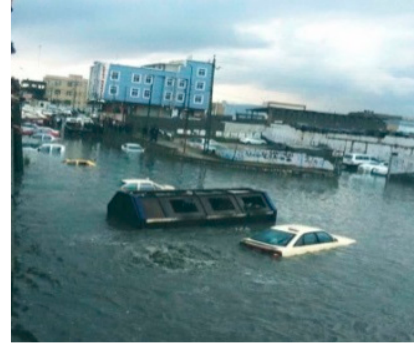

(e)

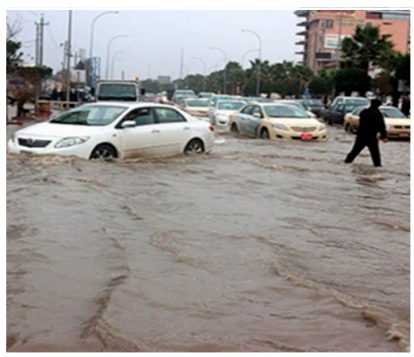

(c)

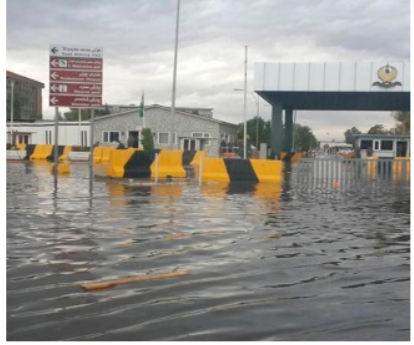

(f)

Figure 1. Failure scenarios of the existing conventional drainage system at different sites in Erbil city: (a) Kirkuk Road flooded on 28 January 2014 (photo obtained from Erbil Governorate; (b) Gulan District flooded on 28 January 2014 (photo taken by Mohammed A. Nanekely); (c) $60 \mathrm{~m}$ of the Ring Road flooded on 11 September 2015 (photo obtained from Erbil Sewerage Directorate); (d) Zhiyan District flooded on 30 December 2015 (photo taken by Mohammed A. Nanekely); (e) Saidawa District flooded on 30 December 2015 (photo obtained from Erbil Sewerage Directorate) and (f) Ministry's Council Gate flooded on 30 December 2015 (photo obtained from Erbil Governorate).

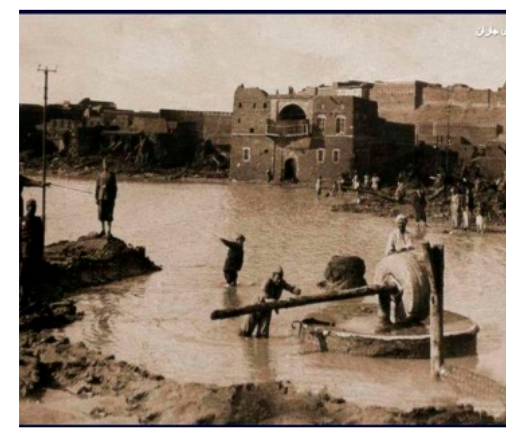

(a)

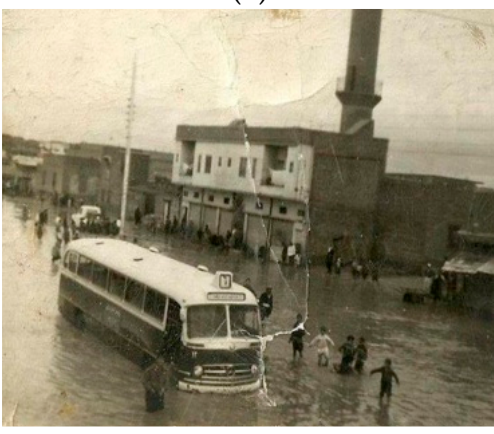

(c)

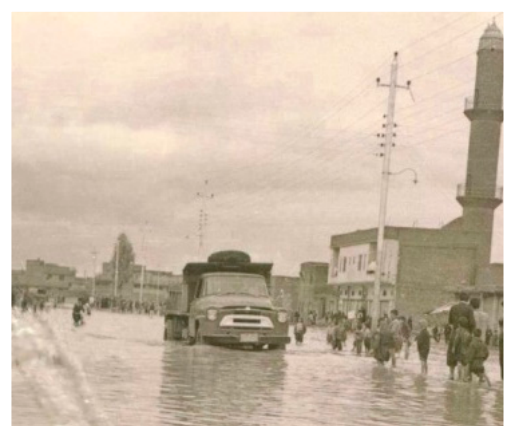

(b)

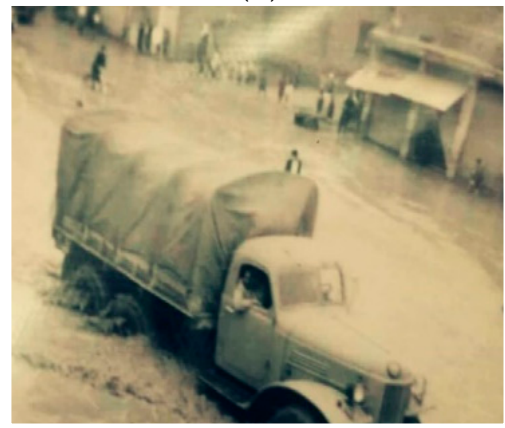

(d)

Figure 2. Historic drainage system under-performances in Erbil city: (a) City center of Khanaqahin 1936 (Erbil Governorate archive); (b) City center of Tayrawain 1960 (Erbil Governorate archive); (c) City center of Tayrawain 1967 (Erbil Governorate archive); and (d) City center of Tayrawain 1970 (Erbil Governorate archive). 


\subsection{Aim, Objectives and Application}

This paper aims to develop a generic platform supporting strategic plans for sustainable drainage system (SuDS) implementation and management in Erbil city and elsewhere. The objectives of this study are to assess (a) the role of SuDS as a compensatory measure in water scarce areas; (b) water scarcity in decision-making processes; (c) the lack of legislation and regulations to implement SuDS; (d) adverse effects of climate change and variability on the existing urban drainage system; and (e) potential effects of increased population and a growing number of displaced people on the implementation of SuDS.

The proposed platform can also be adopted by other cities and regions that have similar characteristics and conditions such as Jinancity in China [19], Xàtiva and Benaguasill (Valencia region) in Spain [20-22], the Gaza Strip in Palestine [23], Haifaand Tel Aviv in Israel [24], Greater Mendoza in Argentina [25], and The South Fork of Chollas Creek, which is located southeast of downtown San Diego (California and Colorado) in the USA [26,27].

\section{Materials and Methods}

\subsection{Erbil City as a Case Study}

Erbil city (also known as Hawler) is located in the northern part of Iraq and is the capital of the Kurdistan region. Erbil province covers an area of $14,873 \mathrm{~km}^{2}$ [28]. The governorate had a population of about 2,062,380 people in 2015, which included roughly 358,260 internally displaced people. Erbil city spans an area of about $491 \mathrm{~km}^{2}$ (about $3.3 \%$ of the Erbil province) with a population of approximately $1,341,130$ including about 232,870 internally displaced people [29].

\subsection{Methodology}

A solid integrated and joint methodology was used to achieve the objectives and appropriately demonstrate the results. The methodology is a combination between a self-administrated questionnaire, face-to-face communication and interviews, and electronic media interaction. An on-line questionnaire was designed and five workshops, targeting multidisciplinary cohorts (hydrologists, ecologists, civil engineers and ecologists), were conducted in 2015. Mitchell [30] pointed out that "using a self-administered questionnaire can be a cheap and easy way to get honest answers". Similarly; Mbaofficial.com [31] stated that the advantages are low-cost, high reliability, time-saving and high suitability for collecting large samples. Face-to-face communication and interviews (including the exchange of ideas, information, feedback and constructive comments) and electronic media (i.e., direct e-mails and LinkedIn professional networking) were used to target a high number of potentially authoritative responders such as academics and Ph.D. students at universities, researchers at research institutes and decision-makers in relevant industries.

The main reason for selecting particular categories of cohorts is that they usually comprise professionals with good knowledge and experience, which is likely to lead to more objective and scientific results. Questions were grouped into a solid set of classes (Appendix A). The statistical analysis was performed using the International Business Machines software package for statistical analysis version 20 (IBM SPSS 20; IBM Corporation, Armonk, NY, USA) [32] in an attempt to convert the responses to informative output.

In 2015, 337 individuals, representing $35 \%$ of "various" organisations, $30 \%$ of local councils, $17 \%$ of government commissions, $12 \%$ of the local community and $6 \%$ from the private sector participated in the interviews and workshops undertaken for this study. Participants were involved in the project via either individual face-to-face interviews and/or telephone conversations. The interviews were used to investigate current and future foreseeable water scarcity, as well as impacts of water scarcity on ecosystems, agriculture, industry and domestic users. The relationship between water scarcity and sustainable management of water and drainage practices, as well as the socio-economic drivers and their influences on water resources management in a sustainable manner, were also assessed. 
Moreover, the study examined the likelihood of growing conflicts among multi-water use stakeholders as a consequence of a water shortage.

The interviews and the workshops were structured to identify individuals who can offer good insight and who represent a spectrum of experiences and opinions. Semi-structured interview techniques [33] were adopted in this study. The interviews were undertaken by a number of well-designed inter-connected specific questions (Appendix A) to effectively engage diverse groups of people and to ensure integrity, consistency and comparability of the data gained through the questionnaire, interview and workshop processes.

Prior to conducting the interviews and workshops, ethical approvals from the Ministry of Municipalities and Tourism (Kurdistan Region, Iraq) were obtained. The questions listed in the questionnaire were categorized into six themes (Figure 3): (a) challenges to decision-makers; (b) business management; (c) strategic planning, legislation and regulation; (d) sustainability; (e) climate change and variability; and (f) social and environmental aspects.

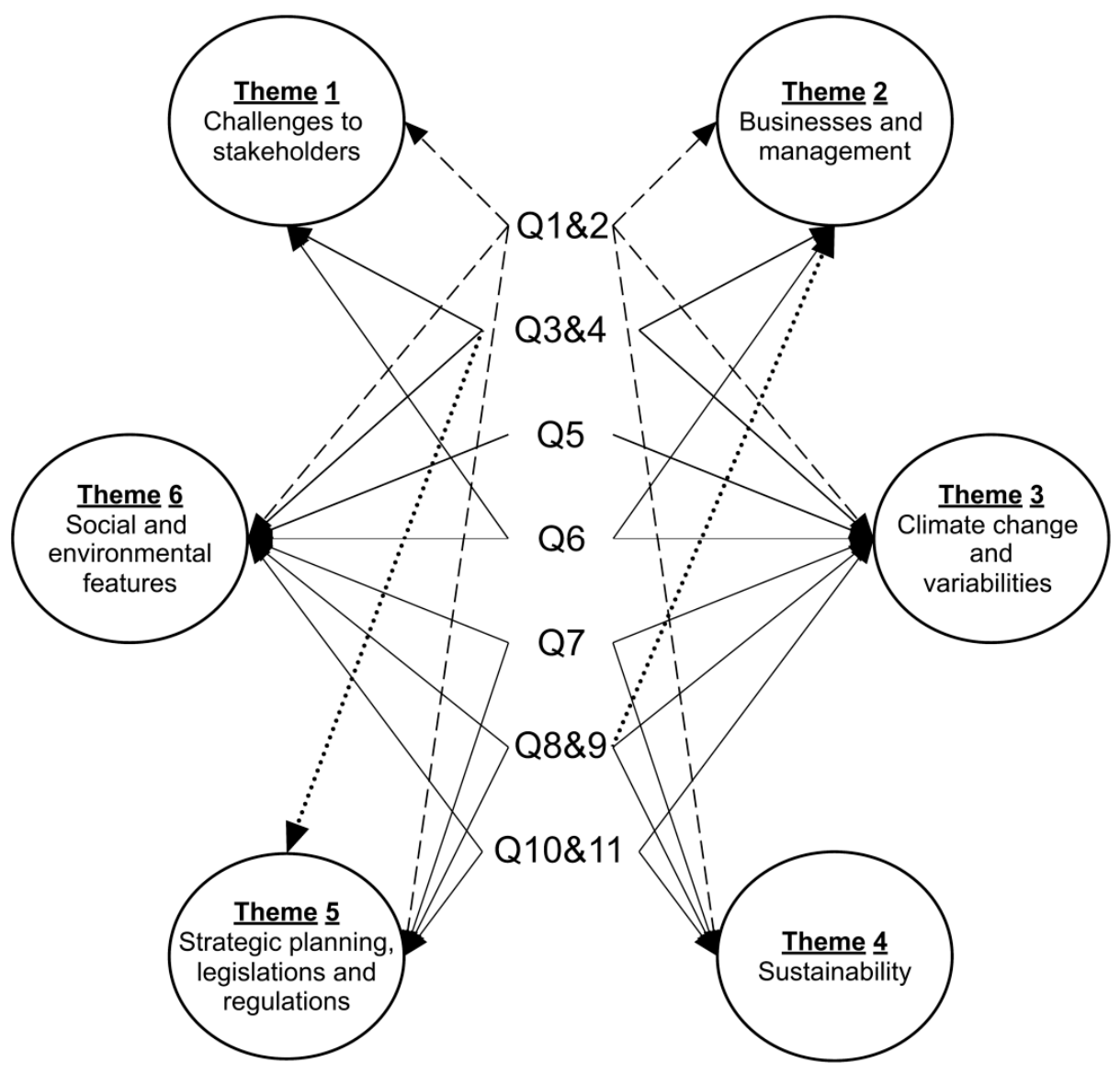

Figure 3. Spectrum of adopted themes.

Table 1 lists the meteorological stations, and their corresponding coordinates and altitudes. Annual precipitation and temperature data between 1980 and 2014 observed at seven meteorological stations located within or in close proximity to Erbil city (Figure 4). Data analysis using Microsoft Office (Excel) was conducted to demonstrate the long-term trend in precipitation and temperature data between 1980 and 2014. The analysis allows the user to add trend lines. The correlation coefficient relevant to each equation was calculated using the least squares method. This was achieved by asking the interviewees to rank their responses for each question entry on a scale, for example, from 1 to 4 , where 1 may represent the lowest and 4 the highest characterization (e.g., threat or impact) as shown in Appendix A. Statistical significance was also tested using the software Excel. 
Table 1. Coordinates and altitude of the meteorological stations.

\begin{tabular}{cccc}
\hline Stations & Longitudes & Latitudes & Altitudes (masl) \\
\hline 1 & 43.7500 & 36.3747 & 401 \\
2 & 44.0625 & 36.3747 & 507 \\
3 & 44.3750 & 36.3747 & 977 \\
4 & 44.0400 & 36.1950 & 414 \\
5 & 43.7500 & 36.0624 & 278 \\
6 & 44.0625 & 36.0624 & 439 \\
7 & 44.3750 & 36.0624 & 605 \\
\hline
\end{tabular}

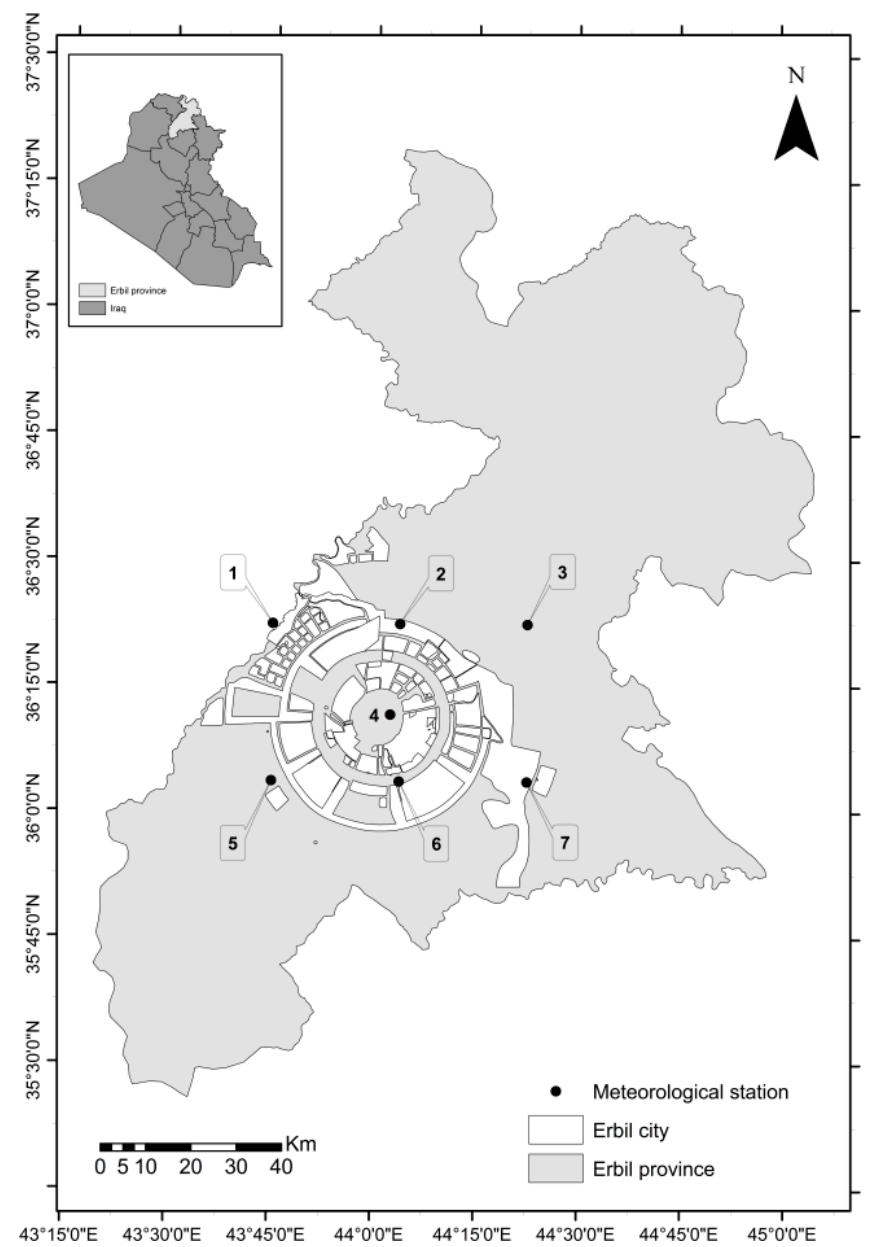

Figure 4. Erbil city and locations of corresponding meteorological stations.

\section{Results and Discussion}

The long-term total annual precipitation and the mean annual temperature observed between 1980 and 2014 were about $595 \mathrm{~mm}$ and $20.0^{\circ} \mathrm{C}$, respectively. The maximum and minimum total annual rainfall of $1552 \mathrm{~mm}$ and $128 \mathrm{~mm}$ were observed in 2013 and 2008 in this order. The maximum and minimum mean annual temperatures of about $24.0^{\circ} \mathrm{C}$ and $16.0^{\circ} \mathrm{C}$ were recorded in 2014 and 1992 in this order. A negative trend (Figure 5) was associated with total annual precipitation observed between 1980 and 2014 in all stations except station 3, indicating a drop in the amount of precipitation. As far as the rate of temperature is concerned, a positive trend (Figure 6) was perceived in all stations, showing growth in the rate of temperature.

Table 2 shows the Pearson's correlation coefficients between the themes. The values of the correlation coefficient fall between 0.728 and 0.967 . The lowest correlation coefficient of 0.728 was 
observed between Theme 1 and Theme 4, while the highest value of correlation coefficient of 0.964 was witnessed between Theme 3 and Theme 6 .

Results indicate that the normal condition was associated with $51 \%$ of the water years, and $26 \%$ were wet years, while the remaining $23 \%$ were dry years. The lowest annual precipitation of $130 \mathrm{~mm}$ was recorded in 2008, accounting for about $23 \%$ of the long-term average annual precipitation. The years 1999, 2000 and 2009 were associated with considerably lower precipitation than what can be considered as average: $36 \%, 42 \%$ and $53 \%$, respectively.

Questionnaire results reveal the following challenges to decision-making: conflicts $(45.5 \%)>$ health $(23.1 \%)>$ economic growth $(19.8 \%)>$ social poverty $(11.6 \%)$. No significant differences were observed ( $p$-value of 0.083 ) between the influences of these challenges in the decision-making process. Dynamic involvement of the local community in planning, decision-making and monitoring is essential. The beneficiaries (local authorities, environment agencies and local communities) should enjoy sufficient flexibility to choose the service level that responds well to their needs and capacities. Ownership or, at least, co-ownership of sustainable drainage infrastructure by the local community is crucial for long-term management in a sustainable manner. Moreover, effective participation of the local community at all age stages of a sustainable drainage project will positively contribute to a sense of ownership, helping to ensure that the services provided to the community are based on their needs, priorities and affordability.
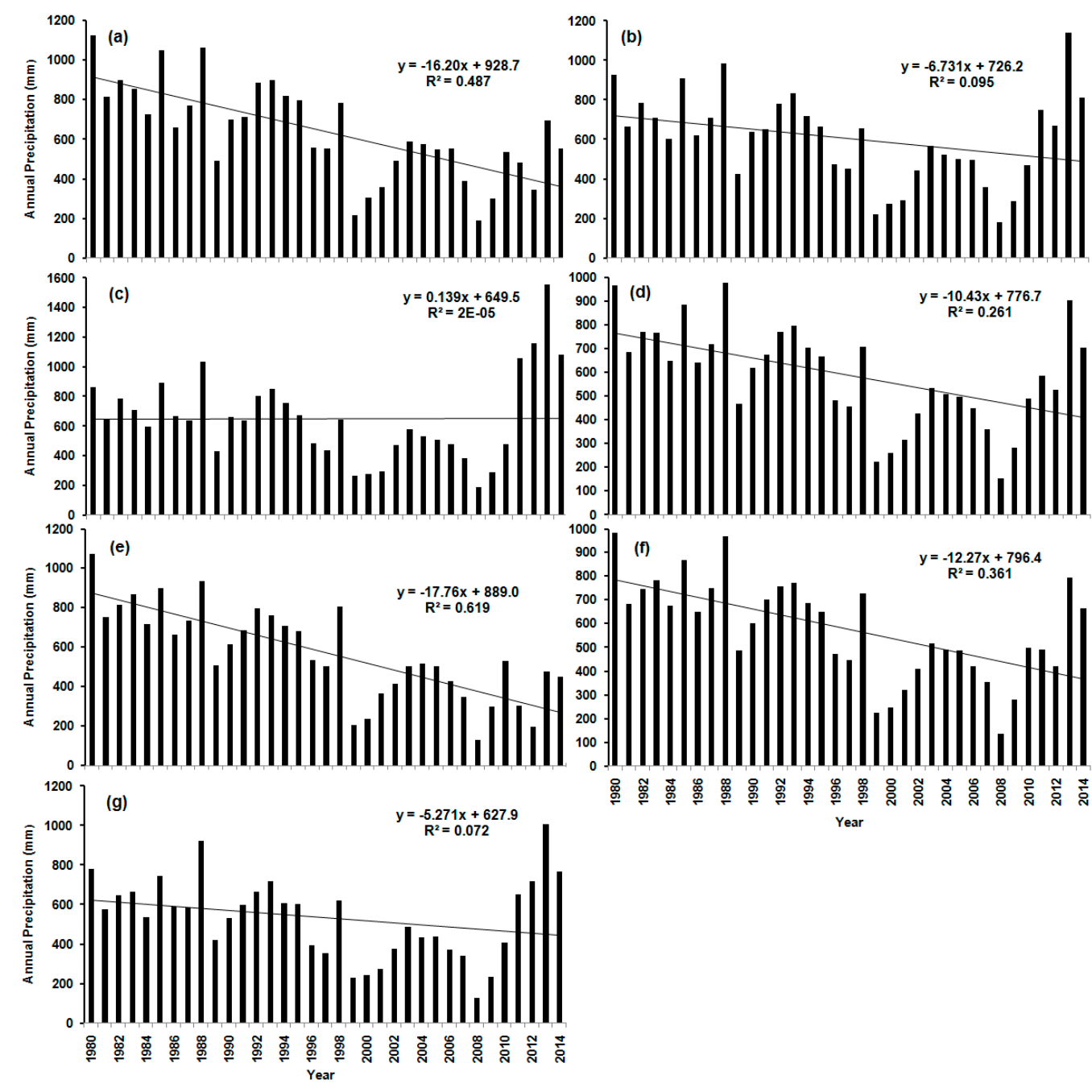

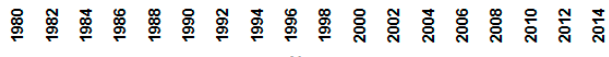

Figure 5. Annual variation in precipitation of meteorological weather stations: (a) station 1; (b) station 2; (c) station 3; (d) station 4; (e) station 5; (f) station 6; and (g) station 7. 


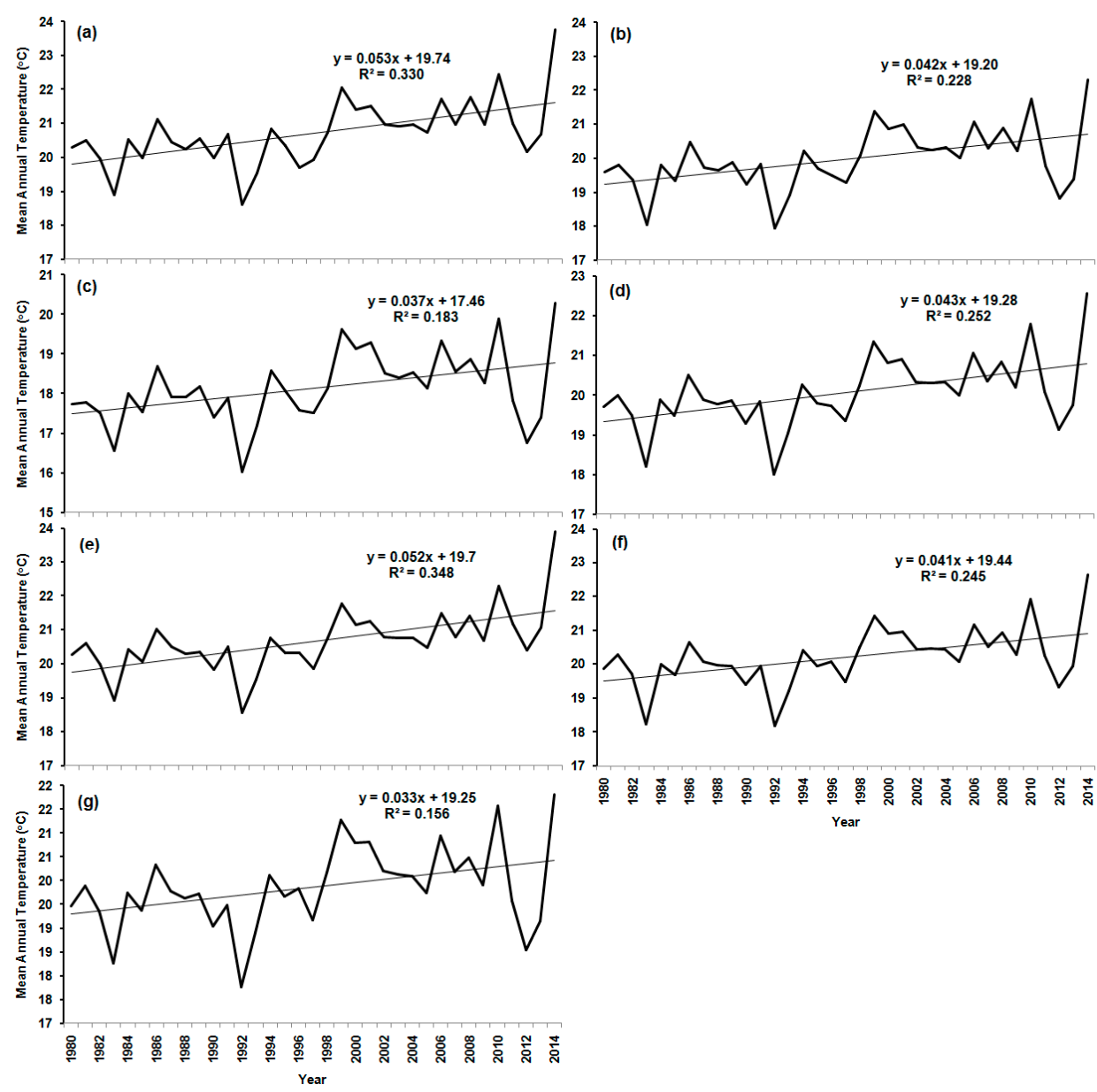

Figure 6. Annual variation in mean annual temperature at the meteorological weather stations: (a) station 1; (b) station 2; (c) station 3; (d) station 4; (e) station 5; (f) station 6; and (g) station 7.

The financial and physical influences were of similar importance, accounting for approximately $85 \%$ of the total influence on business wellness and productivity. The collective risks related to the regulation and business reputation features accounted for around $15 \%$.

The private sector should be actively supported in initiating capacities for investment, building and coherent service delivery. Creating a public-private partnership would be effective, particularly during the initial stage, which supports the rehabilitation of the existing infrastructure, improves efficiency and service quality of utilities as well as setting-up new sustainable drainage projects. Moreover, economic water scarcity is an outstanding issue that has to be avoided. Accordingly, there is a need for regulatory and enhancement measures to secure the proper engagement of the private sector and provide an appropriate atmosphere for safe investment.

Regulations of water supply and sanitation services are dispersed between several ministries and agencies bringing challenges and difficulties associated with complex coordination mechanisms and consistency. In this regard, effort is required to introduce incentives to encourage solidarity among the various regulatory bodies with diverse responsibilities (e.g., public health management, drinking water quality and licensing of water utilities) and to advance regulatory capacity at various levels. Moreover, outdated or restrictive regulations need to be identified and updated.

Results drawn from the questionnaire (questions 3 and 6) and outcomes from discussions during workshops (academics and decision-makers) show that the construction of water and sanitation facilities contributes to an increase in man-power and reduces the unemployment proportion. This is not limited to the implementation period, but further to the long-term management, operation and maintenance needs. 
Table 2. Correlation coefficients between themes (correlations are significant at the 0.01 level).

\begin{tabular}{ccccccc}
\hline Theme Number & Theme 1 & Theme 2 & Theme 3 & Theme 4 & Theme 5 & Theme 6 \\
\hline 1 & 1.000 & 0.953 & 0.835 & 0.728 & 0.914 & 0.894 \\
2 & - & 1.000 & 0.895 & 0.832 & 0.964 & 0.947 \\
3 & - & - & 1.000 & 0.890 & 0.920 & 0.967 \\
4 & - & - & - & 1.000 & 0.908 & 0.882 \\
5 & - & - & - & - & 1.000 & 0.963 \\
6 & - & - & - & - & - & 1.000 \\
\hline
\end{tabular}

Findings also indicate that climate change will pose an enormous challenge to the current combined conventional drainage system in terms of capacity while coping with increasing runoff. Urban drainage facilities should be developed in cooperation with water resources management stakeholders and utilities, using an integrative approach. Water use should be sustainable and abide by environmental guidelines. Wastewater disposal should be planned and managed with a view to minimising environmental impact and ensuring water resources protection.

Concerning the tested environment-related issues pollution increase, green area reduction, dust storm increase and wilderness increase, the highest mark $(40.4 \%)$ was associated with the increase in pollution followed by shrinkage in green areas (31.5\%), while the increase in dust storm and wilderness were found to be about $14.1 \%$. The results indicate that perceptions regarding environmental phenomena are influenced by the scarcity of water and its mismanagement. An increase of pollution is attributed to the advancement of industry and agriculture, which has led to an increase in population and the demand by most people for a higher standard of living, all triggering an increase in water consumption. At the same time, wastewater discharges also worsen the situation.

The indifference for the sustainable management of water, rainwater harvesting, the use of SuDS techniques, and source control of storm water and groundwater conservation has led to water shortages. As a consequence, decreases in water supply for irrigation in agriculture have been observed.

\section{Conclusions and Recommendations}

The results are based on an integrated methodology, incorporating a self-administrated questionnaire, workshops, face-to-face communication and interviews coupled with electronic media interactions. Concerning challenges to decision-making, findings point out that the highest rate was given to conflicts accounting for nearly $46 \%$, while the lowest proportion was linked to social poverty $(12 \%)$. About $23.1 \%$ and $19.8 \%$ were associated with health and economic growth, respectively. Results indicated that nearly $85 \%$ of the total risks were related to financial and physical attributes. Approximately $15 \%$ of the risks were associated with both regulations and business reputation features. Findings also show that Erbil city tends to experience drier and warmer weather conditions.

Revisions and amendments of environmental acts, laws and regulations are essential to promote water conservation and investments in integrated water resources management. Urban drainage systems face an increased challenge to meet the demands linked to a growing population, including an increase of internally displaced people. Therefore, a capacity assessment should be conducted to identify the current capacity gaps and potential future needs, develop a solid action plan for short- to long-term capacity building programmes, and put into practice a coherent monitoring and evaluation process and measures to ensure that the implementation is thoroughly followed-up.

It is also recommended to prepare an inclusive curriculum on primary health care, which highlights the importance of hygiene and the urgent need to access safe drinking water and basic sanitation facilities. This should be incorporated into short-, medium- and long-term media campaigns that utilise all possible measures including the internet, television, radio and newspapers.

Acknowledgments: Some material has been provided by the Kurdistan Regional Government of Iraq (Ministry of Municipality) and Shuokor Q. Aziz (Civil Engineering Department, Salahaddin University, Erbil, Iraq). The University of Salford supported the upload of the questionnaire via the Bristol online survey tool. The Kurdistan Regional Government is also supporting a Ph.D. studentship for the lead author. 
Author Contributions: Mohammed Nanekely undertook the questionnaire campaign and held seminars. He also provided the first paper draft. Miklas Scholz and Furat Al-Faraj edited various paper versions including the final one.

Conflicts of Interest: The authors declare no conflict of interest.

\section{Appendix A}

(The questionnaire form)

I am Mohammed A. Nanekely, currently studying for a Ph.D. degree at The University of Salford, United Kingdom. The Kurdistan Region was used as a case study to conduct a research project on Sustainable Drainage Systems (SuDS). You are invited to address a number of questions. There are no right or wrong answers. These questions are used for purely academic and scientific purposes. The interviewee's names and any information you give will be anonymous, and would be treated with professionalism and strict confidentiality. Answering all questions accurately will help the researcher in this area.

Many thanks for your co-operation and efforts to serve the scientific process.

Q1: Are you interested in water issues or belong to one of the following cohorts? If yes, please answer the rest of questions. If no, thank you so much for your well-intention and generosity.

- Civil Engineers

- Hydrologists

- Environmentalists

- Ecologists

Q2: Give your view on the seriousness of water scarcity in the 21st century.

Please indicate, on a scale from 1 to 5 , where 1 is not at all serious and 5 is extremely serious. Insert your entry here:

Q3: Which aspect is most related to water scarcity, resulting in a challenge to government?

Please indicate, on a scale from 1 to 4 , where 1 is least and 4 is most related.

\section{Conflict}

Economic growth

Health

Social poverty

Q4: Which risk does water scarcity pose to business?

Please indicate, on a scale from 1 to 4 , where 1 is lowest and 4 is the highest threat.

Financial risk (e.g., rise of prices and low investment)

Physical risk (e.g., drought and/or flooding)

Regulatory risk (e.g., change of laws due to water scarcity)

Reputational risk (e.g., loss of customers)

Q5: Which environmental phenomenon is most related to water scarcity?

Please indicate, on a scale from 1 to 4 , where 1 is least and 4 is most related.

Dust storm increase

Green area reduction

Pollution rate increase

Wilderness increase 
Q6: Which of the following risk has the greatest impact on human life?

Please indicate, on a scale from 1 to 3, where 1 is fewest and 4 is the greatest impact.

Risk to business

$\square$ Risk to environment

Risk to government

Q7: Which sustainable urban storm water management benefits are important for you?

Please indicate, on a scale from 1 to 5 , where 1 is not at all serious and 5 is extremely serious.

Groundwater recharge:

Increase in public amenity:

Increase in biodiversity:

Supporting sustainability:

Water quality improvement:

Water quantity management:

Water recycling:

Other benefits (please state and rate):

Q8: Do you think that the use of Sustainable Drainage Systems will contribute to addressing the issue of water scarcity?

Yes

No

Q9: In your opinion, to what extent can the use of Sustainable Drainage Systems be considered as an influential factor in water re-use?

Please select only one option or indicate your estimation below:

$\square$ about $25 \%$ (i.e., one of many important factors)

$\square$ about $50 \%$

$\square$ about $75 \%$

$\square$ about $100 \%$ (i.e., the most and virtually only factor)

Alternatively, insert your entry here: $\%$

Q10: Do you believe that the use of sustainable drainage systems in semi-arid regions will be successful, despite of global climate change challenges?

Yes

No

Q11: In your opinion, to what extent is the use of sustainable drainage systems likely to be successful in cities that have not yet taken these systems into consideration (i.e., not yet part of the master planning or design sector planning)?

Please select only one option or indicate your estimation below:

$\square$ about $25 \%$ (i.e., one of many potentially successful options)

$\square$ about $50 \%$

$\square$ about $75 \%$

$\square$ about $100 \%$ (i.e., absolutely certain to be successful)

Alternatively, insert your entry here: $\%$

Thank you for your valuable time. 


\section{References}

1. Al Obaidy, A.H.M.J.; Al-Khateeb, M. The challenges of water sustainability in Iraq. Eng. Technol. J. 2013, 31, 828-840.

2. Tokyo Engineering Consultants Co., Ltd.; Nippon Koei Co., Ltd. The Feasibility Study on Improvement of the Water Supply System in Al-Basrah City and Its Surroundings in the Republic of Iraq; Japan International Cooperation Agency: Tokyo, Japan, 2007; pp. 13-124.

3. Al-Ansari, N. Management of Water Resources in Iraq: Perspectives and Prognoses. Engineering 2013, 5, 667-684. [CrossRef]

4. United States Government Accountability Office. Rebuilding Iraq. Report to Congressional Committees. GAO-05-872 Iraq Water and Sanitation. 2005. Available online: http://www.gao.gov/new.items/d05872.pdf (accessed on 14 September 2016).

5. Al-Faraj, F.; Scholz, M.; Tigkas, D.; Boni, M. Drought indices supporting drought management in transboundary watersheds subject to climate alterations. Water Policy 2015, 17, 865-886. [CrossRef]

6. United Nations Educational, Scientific and Cultural Organization-International Research and Training Centre on Erosion and Drainage. Urban Drainage in Specific Climates; Technical Documents in Hydrology; UNESCO: Paris, France, 2011; Volume 3, No. 40.

7. Isis Closes Ramadi Dam Gates, Cutting off Water to Pro-Government Towns. Available online: https:/ / www.theguardian.com/world/2015/jun/03/isis-closes-ramadi-dam-gates-cutting-off-water-topro-government-towns (accessed on 16 June 2016).

8. In Their Latest Outrage, Islamic State Fighters Are Using Water as a Weapon in Iraq. Available online: https://www.washingtonpost.com/world/middle_east/islamic-state-jihadists-are-using-water-as-a-weaponin-iraq/2014/10/06/aead6792-79ec-4c7c-8f2f-fd7b95765d09_story.html (accessed on 16 June 2016).

9. Ghani, A.; Zakaria, N.; Chang, C.; Ainan, A. Sustainable Urban Drainage System (SUDS)—Malaysian Experience. In Proceedings of the 11th International Conference on Urban Drainage, Edinburgh, UK, 31 August-5 September 2008; pp. 1-10.

10. Zakaria, N.; Ghani, A.; Ayub, K.; Ramli, R. Sustainable Urban Drainage System. In Proceedings of the 2nd International Conference on Managing Rivers in 21st Century: Solutions towards Sustainable River Basins, Kuching, Sarawak, Malaysia, 6-8 June 2007; pp. 21-26.

11. Al-Faraj, F.; Scholz, M.; Tigkas, D. Sensitivity of Surface Runoff to Drought and Climate Change: Application for Shared River Basins. Water 2014, 6, 3033-3048. [CrossRef]

12. Al-Faraj, F.; Tigkas, D.; Scholz, M. Irrigation efficiency improvement for sustainable agriculture in changing climate: A transboundary watershed between Iraq and Iran. Environ. Process. 2016. [CrossRef]

13. Al-Faraj, F.; Scholz, M. Impact of basin-wide dry climatic conditions and non-climatic drivers: An isolation approach. J. Water Clim. Chang. 2016. [CrossRef]

14. Modesto Gonzalez Pereira, M.G.; Sanches Fernandes, L.F.; Barros Macário, E.M.; Gaspar, S.M.; Pinto, J.G. Climate change impacts in the design of drainage systems: Case study of Portugal. J. Irrig. Drain. Eng. 2015, 141, 05014009. [CrossRef]

15. Intergovernmental Panel on Climate Change. Long-Term Climate Change: Projections, Commitments and Irreversibility. Available online: http://www.ipcc.ch/pdf/assessment-report/ar5/wg1/WG1AR5_ Chapter12_FINAL.pdf (accessed on 2 January 2016).

16. KRG Draft Water and Sanitation Policy. Available online: http://www.watsan-krg.org/ (accessed on 15 March 2014).

17. ساروزكايهنيشارموانيهاوليّر (English Site Under Construction). Available online: http://www.pom-erbil.org (accessed on 13 May 2016).

18. Directorate General of Meteorology and Seismology. The Annual Weather Report for Iraqi Kurdistan Region Cities; Ministry of Communication and Transportation-KRG: Erbil, Iraq, 2016.

19. Yang, R.; Cui, B. Framework of Integrated Stormwater Management of Jinan City, China. Procedia Environ. Sci. 2012, 13, 2346-2352. [CrossRef]

20. Perales-Momparler, S.; Andres-Domenech, I.; Andreu, J.; Escuder-Bueno, I. A Regenerative Urban Stormwater Management Methodology: The Journey of a Mediterranean City. J. Clean. Prod. 2015, 109, 174-189. [CrossRef] 
21. Casal-Campos, A. Selecting SUDS in the Valencia Region of Spain. Water Pract. Technol. 2012, 7, 1-9. [CrossRef]

22. Perales-Momparler, S.; Jefferies, C.; Perigüell-Ortega, E.; Peris-García, P.; Muñoz-Bonet, J. Inner-City SUDS Retrofitted Sites to Promote Sustainable Stormwater Management in the Mediterranean Region of Valencia: AQUAVAL (Life+ EU Programme). In Proceedings of the 8e Conference Internationale NOVATECH, Lyon, France, 24-26 June 2013; pp. 1-10.

23. Khalaf, A.R. Assessment of Rainwater Losses Due to Urban Expansion of Gaza Strip. Master's Thesis, The Islamic University of Gaza, Gaza City, Palestine, 2005.

24. Carmon, N.; Shamir, U. Water-Sensitive Planning: Integrating Water Considerations into Urban and Regional Planning. Water Environ. J. 2009, 24, 181-191. [CrossRef]

25. Vich, A.; Rodríguez, M.; Lauro, C.; Vaccarino, E. Proposals for Flashflood Management in Western Argentina. Case Study: The Metropolitan Area of Greater Mendoza. Curr. Urban Stud. 2014, 2, 37-48. [CrossRef]

26. Hawley, R.; Bledsoe, B. How Do Flow Peaks and Durations Change in Suburbanizing Semi-Arid Watersheds? A Southern California Case Study. J. Hydrol. 2011, 405, 69-82. [CrossRef]

27. Urbonas, B. Effectiveness of Urban Stormwater BMPs in Semi-Arid Climates. In Proceedings of the Regional Conference on Experience with Best Management Practices, Denver, CO, USA, 9 April 2003; pp. 1-13.

28. Kurdistan Region Statistics Office. Report on Population Projections for the Kurdistan Region for the Period 2009-2020; Ministry of Planning-KRG: Erbil, Iraq, 2014; p. 16.

29. Iraq Mission, International Organization for Migration. Erbil Governorate Profile, May 2015. Available online: http:/ /iomiraq.net/reports/erbil-governorate-profile-may-2015 (accessed on 28 January 2016).

30. Mitchell, M.; Jolley, J. Research Design Explained, 8th ed.; Jon-David Hague: New York, NY, USA, 2012.

31. Mbaofficial.com. What Are the Types of Questionnaire? Available online: http://www.mbaofficial.com/mba (accessed on 22 April 2015).

32. Wheeler, A. Why I Feel SPSS (or Any Statistical Package) Is Better Than Excel for This Particular Job. Available online: https:/ / andrewpwheeler.wordpress.com/2013/03/30/why-i-feel-spss-or-any-statisticalpackage-is-better-than-excel-for-this-particular-job/ (accessed on 26 February 2016).

33. Newton, N. The Use of Semi-Structured Interviews in Qualitative Research: Strengths and Weaknesses. Available online: http://www.academia.edu/1561689/The_use_of_semi-structured_ interviews_in_qualitative_research_strengths_and_weaknesses (accessed on 5 March 2015). 